Article

\title{
Diverse Effects of $\beta$-Carotene on Secretion and Expression of VEGF in Human Hepatocarcinoma and Prostate Tumor Cells
}

\author{
Huei-Yan Chen, Shu-Ming Huang, Chih-Min Yang * and Miao-Lin Hu * \\ Department of Food Science and Biotechnology, National Chung Hsing University, \\ 250 Kuo Kuang Road, Taichung 402, Taiwan \\ * Authors to whom correspondence should be addressed; E-Mails: s143524@hotmail.com (C.-M.Y.); \\ mlhuhu@nchu.edu.tw (M.-L.H.); Tel./Fax: +886-4-2281-2363.
}

Received: 19 March 2012; in revised form: 30 March 2012 / Accepted: 31 March 2012 /

Published: 2 April 2012

\begin{abstract}
Oral administration of $\beta$-carotene (BC) was found to exert opposite effects on plasma levels of vascular endothelial growth factor (VEGF) in two animal models. One study in nude mice injected via tail vein with hepatocarcinoma SK-Hep-1 cells showed that BC decreases the plasma VEGF level, whereas the other study in nude mice injected subcutaneously with prostate tumor PC-3 cells showed that BC increases the plasma VEGF level. Herein we investigated whether BC $(0.5-20 \mu \mathrm{M})$ possesses diverse effects on VEGF secretion in SK-Hep-1, PC-3 and melanoma B16F10 cells. We found that incubation of SK-Hep-1 cells with BC $(1-20 \mu \mathrm{M})$ for $6 \mathrm{~h}$ significantly decreased VEGF secretion, whereas BC $(1-10 \mu \mathrm{M})$ significantly increased the VEGF secretion in PC-3 cells. However, these effects disappeared at $12 \mathrm{~h}$ of incubation. Similar effects occurred in VEGF mRNA and protein expression after treatment of SK-Hep-1 and PC-3 cells with BC for $6 \mathrm{~h}$. In contrast, $\mathrm{BC}(0.5-20 \mu \mathrm{M})$ did not affect mRNA and protein expression and secretion of VEGF in B16F10 cells. We also found that the proliferation of SK-Hep-1 and B16F10 cells was significantly inhibited by $20 \mu \mathrm{M} \mathrm{BC}$ at 6 and $12 \mathrm{~h}$ of incubation, whereas the proliferation of PC-3 cells was significantly inhibited by $20 \mu \mathrm{M} \mathrm{BC}$ at $12 \mathrm{~h}$ of incubation. In summary, the present study demonstrated the tumor-specific effect of $\mathrm{BC}$ on VEGF secretion in different cancer cell lines.
\end{abstract}

Keywords: B16F10; $\beta$-carotene; PC-3; SK-Hep-1; VEGF 


\section{Introduction}

The role of $\beta$-carotene $(\mathrm{BC})$ on angiogenesis is contradictory. Two studies have indicated that $\mathrm{BC}$ possesses pro-angiogenic activity in endothelial cells and in matrigel-plug model $[1,2]$. One is that $\mathrm{BC}$ $(3.0 \mu \mathrm{M})$ accelerates the basic fibroblast growth factor-induced tube formation and migration of endothelial cells as well as development of microcapillaries in mice with matrigel plug injection subcutaneously [1]. The other is that $\mathrm{BC}$ supplementation $(12,000 \mathrm{mg} / \mathrm{kg})$ in the diet to Balb/c mice with Matrigel-plug transplantation exhibits pro-angiogenic activity [2]. In contrast, one study has indicated that $\mathrm{BC}$ exhibits anti-angiogenic activity by inhibition of B16F10 melanoma-induced neovascularization in vivo and inhibition of proliferation, migration and tube formation in endothelial cells in vitro [3].

Vascular endothelial growth factor (VEGF), an endothelium-specific secreted protein, plays an important role in angiogenesis [4]. Previously, we observed that oral supplementation of BC decreases plasma VEGF levels in nude mice transplanted with hepatocarcinoma SK-Hep-1 cells [5] but increases plasma VEGF in nude mice transplanted with prostate tumor PC-3 cells [6]. Still another study indicated that $\mathrm{BC}$ administration (i.p.) inhibit tumor-specific neovascularization that involved reduction of VEGF expression in lung tissues of B16F10-bearing C57BL/6 mice [3]. Based on these conflicting findings, we hypothesized that the effects of $\mathrm{BC}$ on VEGF expression may be tumor-specific. To test this hypothesis, we investigated the effects of BC on VEGF secretion and mRNA and protein expression in different cancer cell lines including human hepatocarcinoma SK-Hep-1 cells, prostate tumor PC-3 cells, and melanoma B16F10 cells.

\section{Results and Discussion}

Literature reports on the effects of BC on tumor angiogenesis and expression of VEGF are contradictory. Surprisingly, two recent studies of ours demonstrated opposite effects of oral supplementation of BC on plasma VEGF levels in nude mice transplanted with either hepatocarcinoma or prostate tumor cells $[5,6]$. To resolve this issue, we investigated the effects of $\mathrm{BC}$ on VEGF secretion and mRNA and protein expression in vitro in three different cancer cell lines, including hepatocarcinoma SK-Hep-1 cells, prostate tumor PC-3 cells and melanoma B16F10 cells. The main finding was that $\mathrm{BC}(1-20 \mu \mathrm{M})$ significantly decreased VEGF secretion and mRNA and protein expression in SK-Hep-1 cells at $6 \mathrm{~h}$ of incubation, and this effect was U-shaped, i.e., the strongest inhibition ( $30 \%$ for secretion, $P<0.01 ; 49 \%$ for mRNA, $P<0.01$ and $32 \%$ for protein, $P<0.01$ ) occurred at $5 \mu \mathrm{M} \mathrm{BC}$ (Figures 1-3). In contrast, BC (1-10 $\mu \mathrm{M})$ markedly increased VEGF secretion in PC-3 cells in a bell-shaped manner at $6 \mathrm{~h}$ of incubation, i.e., the highest increase (71\% for secretion, $P<0.01 ; 327 \%$ for mRNA, $P<0.01$ and $191 \%$ for protein, $P<0.01$ ) was at $1 \mu \mathrm{M} \mathrm{BC}$ (Figures $1-3$ ). The opposite effects of BC on VEGF secretion in SK-Hep-1 and PC-3 cells appeared to be transient, as they disappeared at $12 \mathrm{~h}$ of incubation (Figure 1). Nevertheless, these results appear to support our previous findings that oral supplementation of $\mathrm{BC}$ decreases the plasma VEGF levels in nude mice xenografted with SK-Hep-1 cells via tail vein [5] but increases the plasma VEGF levels in nude mice injected with PC-3 cells subcutaneously [6]. It is noteworthy that in these two experiments, the effective concentrations ( 5 and $1 \mu \mathrm{M}$ ) of $\mathrm{BC}$ are physiological or supra-physiological, as compared to 
the plasma $\mathrm{BC}$ concentration of $0.56 \mu \mathrm{M}$ in PC-3-bearing nude mice orally supplemented with relatively high $\mathrm{BC}(16 \mathrm{mg} / \mathrm{kg}$ twice a week) for 7 week [6] or the plasma BC levels which increased 14-fold from $0.48 \mu \mathrm{M}$ to $6.83 \mu \mathrm{M}$ in healthy older woman after supplementation with $90 \mathrm{mg} / \mathrm{d}$ $\beta$-carotene for 3 weeks [7].

An in vivo study has shown that BC administration $(60 \mathrm{mg} / \mathrm{kg}$ body weight; i.p., 5 times during a 24-h period) inhibits the neovascularization induced by the melanoma B16F10 cells, suggesting that this effect is, at least in part, associated with the inhibition of VEGF mRNA expression in lung tissues [3]. However, we found in the present study that $\mathrm{BC}(0.5-20 \mu \mathrm{M})$ did not affect the secretion and mRNA and protein expression of VEGF in melanoma B16F10 cells at 6 and $12 \mathrm{~h}$ of incubation (Figures 1-3). It is unclear whether B16F10 cells treated with $\mathrm{BC}$ for longer than $12 \mathrm{~h}$ may result in inhibition of VEGF secretion, as $\mathrm{BC}$ has been shown to be unstable in vitro, and it degrades rapidly in cell culture media ( $\sim 35 \%$ degradation at $24 \mathrm{~h}$ of incubation) [8].

Figure 1. Effect of $\beta$-carotene (BC) on VEGF secretion in SK-Hep-1, PC-3 and B16F10 cells. Cells were incubated with BC $(0-20 \mu \mathrm{M})$ for 6 and $12 \mathrm{~h}$. (A) $6 \mathrm{~h}$; (B) $12 \mathrm{~h}$. Data (means $\pm \mathrm{SD}$ ) are from three or four separate experiments; ${ }^{*} P<0.05$; ${ }^{*} P<0.01$ compared to control $(0 \mu \mathrm{M} \beta$-carotene $)$.
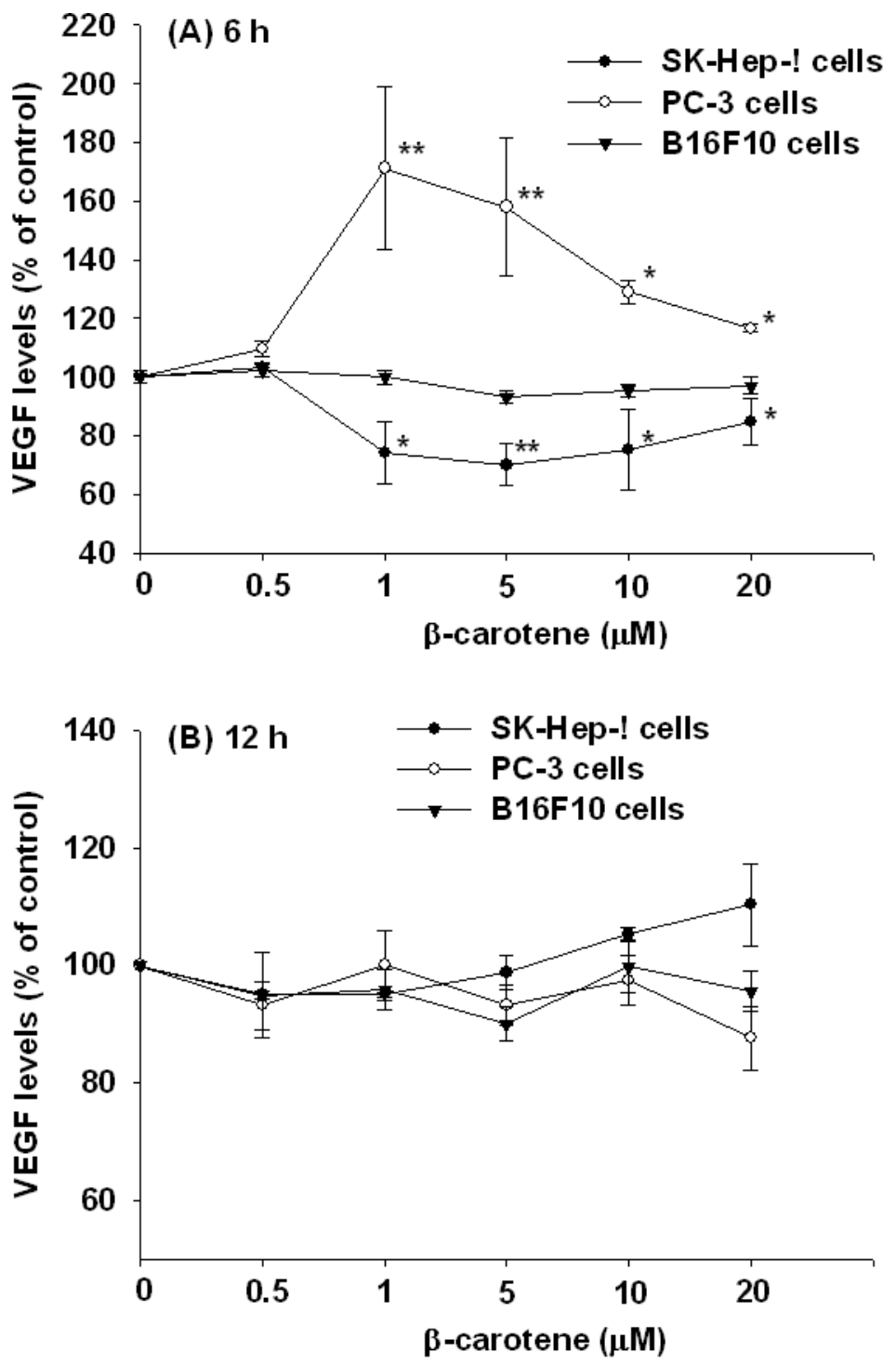
Figure 2. Effect of $\beta$-carotene (BC) on mRNA expression of VEGF in SK-Hep-1, PC-2 and B16F10 cells. Cells were incubated with BC $(0-20 \mu \mathrm{M})$ for $6 \mathrm{~h}$. Data (means $\pm \mathrm{SD}$ ) are from three or four separate experiments; $* P<0.05$; ${ }^{*} P<0.01$ compared to control $(0 \mu \mathrm{M} \beta$-carotene $)$.
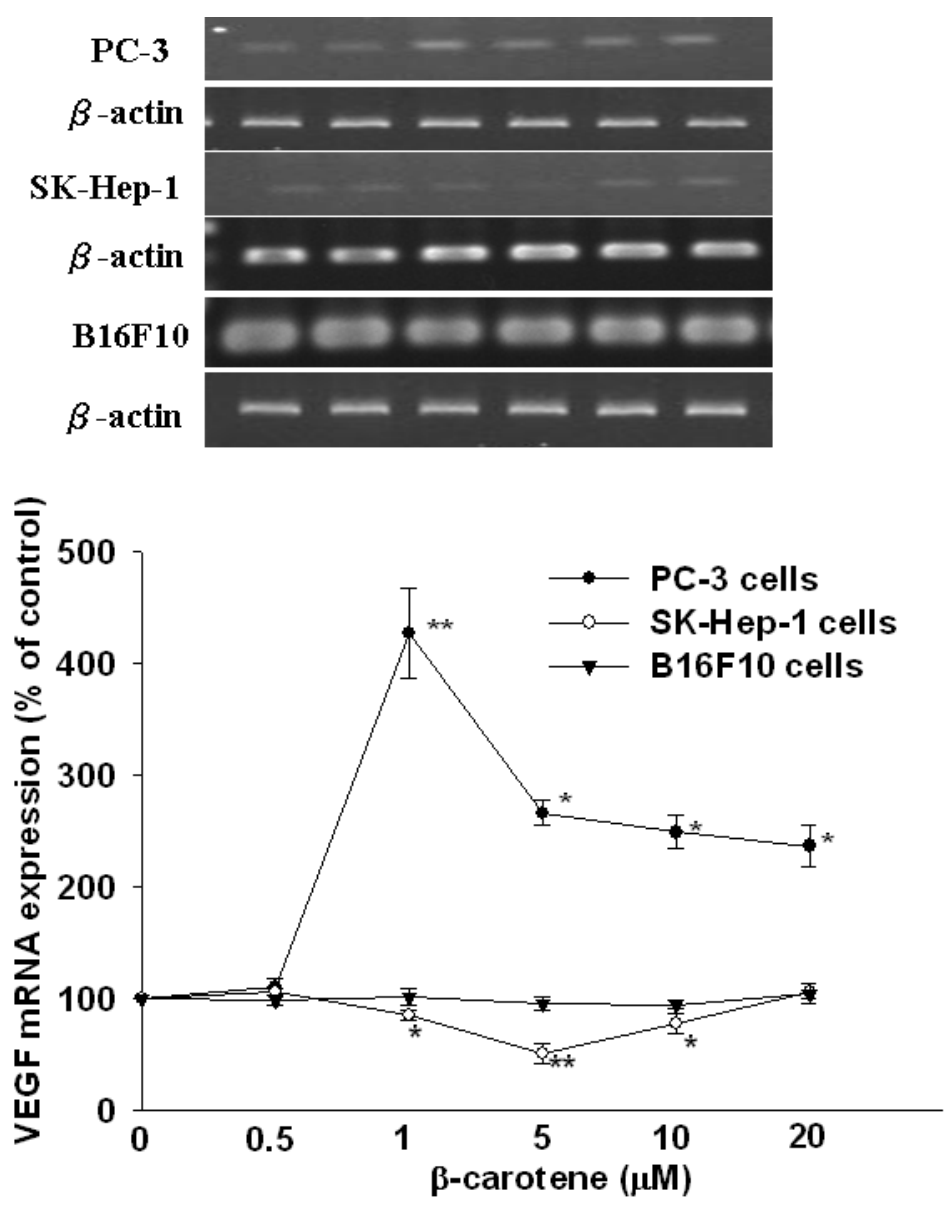

Figure 3. Effect of $\beta$-carotene (BC) on protein expression of VEGF in SK-Hep-1, PC-3 and B16F10 cells. Cells were incubated with BC $(0-20 \mu \mathrm{M})$ for $6 \mathrm{~h}$. Data (means \pm SD) are from three or four separate experiments; * $P<0.05$; ** $P<0.01$ compared to control $(0 \mu \mathrm{M} \beta$-carotene).

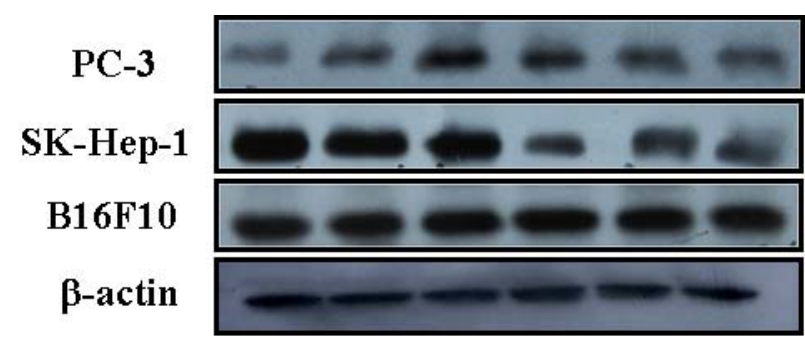


Figure 3. Cont.

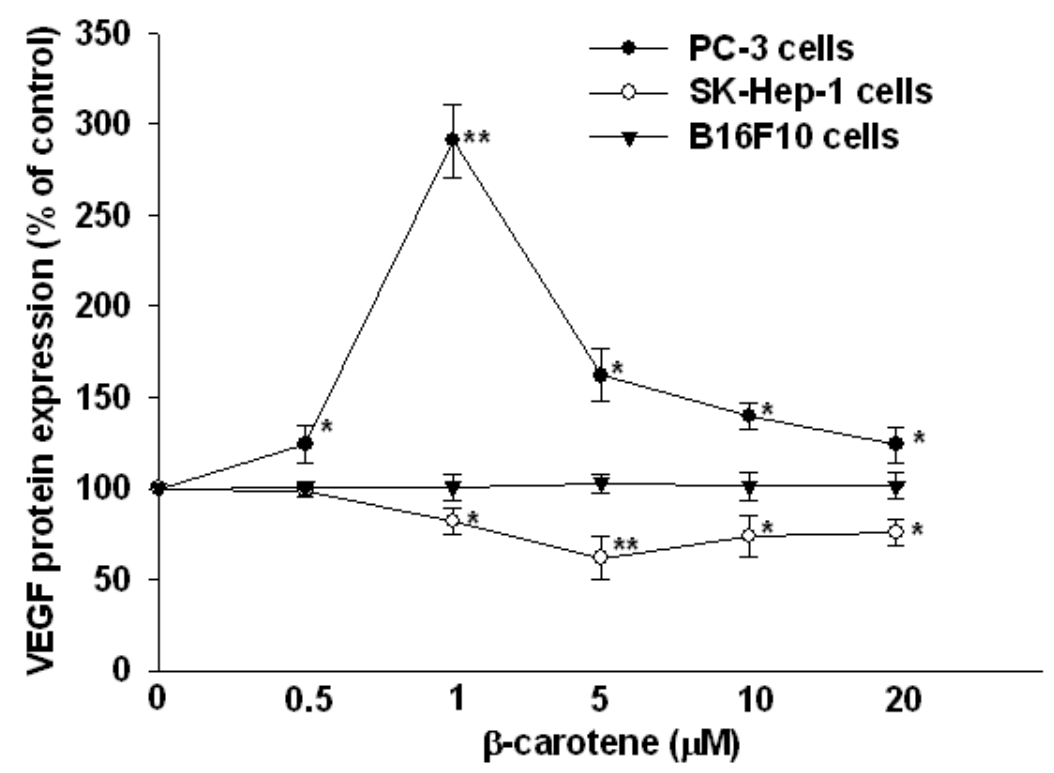

Although BC added at $20 \mu \mathrm{M}$ decreased cell proliferation of all three types of cancer cells, there was no significant inhibition on cell proliferation when $\mathrm{BC}$ added at concentrations lower than or equal to $5 \mu \mathrm{M}$ (Figure 4). In addition, $\mathrm{BC}$ added at concentrations $\leq 5 \mu \mathrm{M}$ with an incubation time of $6 \mathrm{~h}$ either increased (in PC-3 cells) or decreased (SK-Hep-1 cells) VEGF secretion and mRNA and protein expression (Figures 1-3). These results suggest that the modulating effect of BC on VEGF levels in SK-Hep-1 and PC-3 cells is not related to inhibition of cell proliferation.

Figure 4. Effect of $\beta$-carotene (BC) on cell proliferation of SK-Hep-1, PC-3 and B16F10 cells. Cells were incubated with BC $(0-20 \mu \mathrm{M})$ for 6 and $12 \mathrm{~h}$. Data (means $\pm \mathrm{SD}$ ) are from three or four separate experiments; means for each cell type measured at the same incubation time without a common alphabetic letter differ significantly $(P<0.05)$.

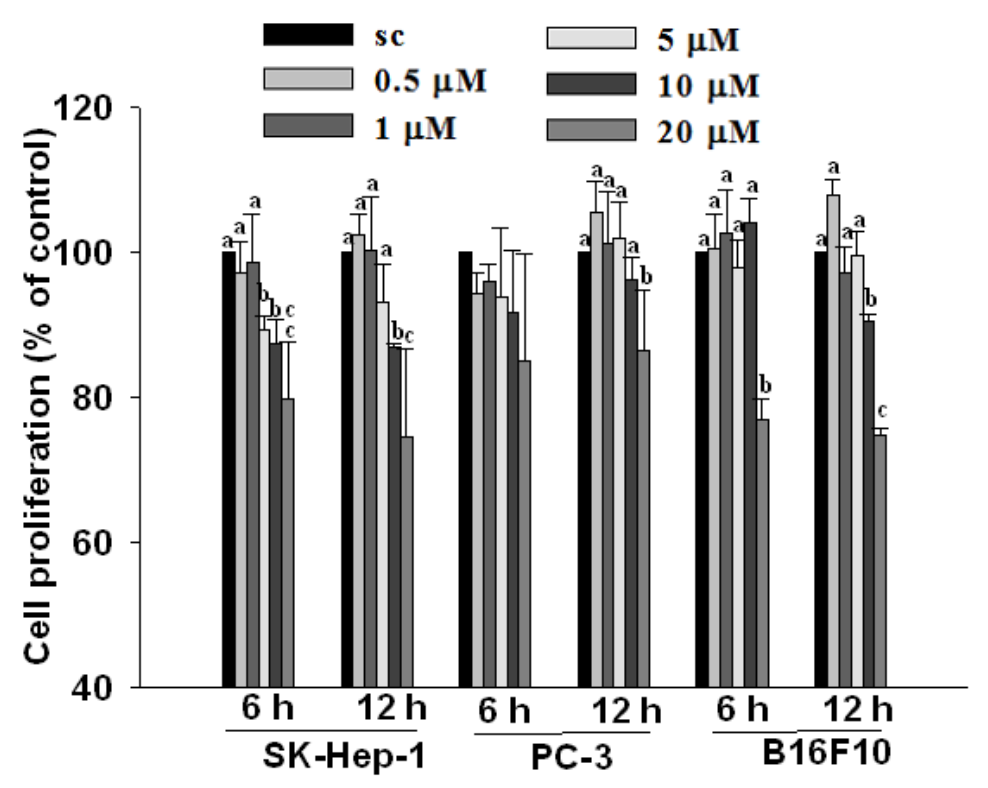


The reason for the U-shaped concentration effect (for SK-Hep-1) and the bell-shaped concentration effect (for PC-3 cells) on VEGF secretion and mRNA expression is unclear. A possible explanation is that, at higher cellular concentrations, the antioxidant property of some carotenoids may shift to prooxidant property [9]. Indeed, some studies have shown that BC exhibits lowered effectiveness as antioxidants and anticarcinogens in cell culture studies at concentrations $>10 \mu \mathrm{M}[9,10]$.

In conclusion, the diverse effects of BC on VEGF secretion in cancer cell lines appear to be tumor-specific. In vivo studies that are carefully designed to elucidate the diverse effects are needed to confirm the present findings.

\section{Experimental}

\subsection{Reagents and $\beta$-Carotene Preparation}

All chemicals used are of the highest grade. Tetrahydrofuran (THF) and butylated hydroxytoluene (BHT) were purchased from Sigma (St. Louis, MO, USA). Dulbecco's Modified Eagle Medium (DMEM), RPMI1640, nonessential amino acid, penicillin/streptomycin, sodium pyruvate, fetal bovine serum (FBS) and trypsin were obtained from Gibco/BRL (Grand Island, NY, USA). $\beta$-Carotene was purchased from Wako (Osaka, Japan), and soluble in THF/BHT to form stock solution of $10 \mathrm{mM}$, which was diluted with THF at 1:1, 1:3, 1:19 and 1:39 ratio, and then diluted with FBS at 1:9 ratio [11]. THF/BHT-FBS- $\beta$-carotene was added to the culture medium at a calculated final concentration of 0.5 , $1,5,10$ or $20 \mu \mathrm{M}$. THF at $0.2 \%(\mathrm{v} / \mathrm{v})$ and FBS at $1.8 \%(\mathrm{v} / \mathrm{v})$ served as the solvent control for beta-carotene, which did not significantly affect the assays described below.

\subsection{Cell Culture and Cell Proliferation Assay}

The human hepatoma SK-Hep-1 cell line (BCRC No. 67005), the mouse skin melanoma B16F10 cell line (BCRC No. 60031) and the human prostate carcinoma PC-3 cell line (BCRC No. 67005) were purchased from the Food Industry Research and Development Institute (HsinChu, Taiwan). SK-Hep-1 cells and B16F10 cells were grown in DMEM medium and PC-3 cells were incubated in RPMI medium containing $10 \%(\mathrm{v} / \mathrm{v})$ fetal bovine serum $(\mathrm{FBS}), 0.37 \%(\mathrm{w} / \mathrm{v}) \mathrm{NaHCO}_{3}$, penicillin $(100 \mathrm{U} / \mathrm{mL})$ and streptomycin $(100 \mathrm{U} / \mathrm{mL})$ in incubator under $5 \% \mathrm{CO}_{2}$ and $95 \%$ air at $37{ }^{\circ} \mathrm{C}$. For the cell proliferation assay, cells were cultured in 24-well plates at $5 \times 10^{4}$ cell/mL containing $0-20 \mu \mathrm{M}$ $\beta$-carotene in $1 \mathrm{~mL}$ serum-free medium for $6,12 \mathrm{~h}$ at $37^{\circ} \mathrm{C}$. Then, the cells were washed with PBS and added $1 \mathrm{~mL}$ of $0.5 \mathrm{mg} / \mathrm{mL}$ 3-(4,5-dimethylthiazolyl-2)-2,5-diphenyltetrazolium bromide (MTT) to incubate for $1 \mathrm{~h}$ at $37{ }^{\circ} \mathrm{C}$. The medium was discarded, and the formazan was dissolved in DMSO and measured spectrophotometrically at $570 \mathrm{~nm}$. The percentage of viable cells was estimated by comparing with untreated control cells.

\subsection{Determination of VEGF Secretion in Cultured Cancer Cells}

SK-Hep-1, PC-3 and B16F10 cells were treated with $\beta$-carotene $(0-20 \mu \mathrm{M})$ for 6 and $12 \mathrm{~h}$ in serum free medium. VEGF levels in the medium were determined using ELISA commercial kit (Endogen Human ELISA Kit, Pierce Biotechnology, Inc., in Rockford, IL, USA) at a wavelength of $450 \mathrm{~nm}$. The assay was performed in three times by following the instruction of the manufacturer. 


\subsection{RNA Extraction and Reverse-transcriptase PCR}

Cellular total RNA was extracted with REzol reagent (Protech, Taipei, Taiwan), and $1 \mu \mathrm{g}$ of total RNA was reverse-transcribed by using oligo-dT as a primer in $20 \mu \mathrm{L}$ reverse-transcription solutions (PROMEGA, USA). The RT-PCR conditions for VEGF and $\beta$-actin were as follows: initial denaturation at $95{ }^{\circ} \mathrm{C}$ for $1 \mathrm{~min}$, and $1 \mathrm{~min}$ annealing time $\left(55^{\circ} \mathrm{C}\right.$ for VEGF and $60{ }^{\circ} \mathrm{C}$ for $\beta$-actin), 1 min amplification time for 40 cycles after an activation step of $2 \mathrm{~min}$ at $95^{\circ} \mathrm{C}$. The PCR products were added $6 \times$ staining buffer (EZVISION THREE DNA DYE \& BUFFER, Amresco, USA) and were subjected to $1 \%$ agarose gel electrophoresis. The primers used in this study were as follows: VEGF forward 5'-AGGAGGAGGGCAGAATCATCA-3', reverse 5'-TCTCGATTGGATGGCAGTAGC-3'; $\beta$-actin forward 5'-GTGGGGCGCCCCAGGCACCA-3', reverse 5'-CACCCCGCGGGGTCCGTGGT-3'. Matrox Inspector 2.1 software was used to quantify the relative level of VEGF.

\subsection{Western Blotting}

Protein expression of VEGF was measured by western blotting. Cells were incubated with BC $(0-20 \mu \mathrm{M})$ for $6 \mathrm{~h}$ and the medium was removed and then cells were rinsed with PBS twice. After the addition of $0.5 \mathrm{~mL}$ of cold RIPA buffer and protease inhibitors cocktail, cells were scraped followed by a vortex at $4{ }^{\circ} \mathrm{C}$ for $20 \mathrm{~min}$. The cell lysates were then subjected to a centrifugation of $12,000 \times \mathrm{g}$ for $30 \mathrm{~min}$ at $4{ }^{\circ} \mathrm{C}$. An amount of protein $(40 \mu \mathrm{g})$ from the supernatant was resolved by SDS-PAGE and transferred onto a PVDF membrane. After blocking with TBS buffer $(20 \mathrm{mmol} / \mathrm{L}$ Tris-HCl, $150 \mathrm{mmol} / \mathrm{L}$ $\mathrm{NaCl}, \mathrm{pH}$ 7.4) containing 5\% nonfat milk, the membrane was incubated with monoclonal antibody followed by horseradish peroxidase-conjugated anti-mouse $\mathrm{IgG}$, and then visualized using an ECL chemiluminescent detection kit (Amersham, Sweden).

\subsection{Statistical Analysis}

Values are expressed as means \pm SD and analyzed using one-way ANOVA followed by LSD for comparisons of group means. All statistical analyses were performed using SPSS for Windows, version 10. Unless specified otherwise, a $P<0.05$ is considered significant.

\section{Acknowledgment}

This research was supported by grants (NSC-97-2320-B-005-003-my3) from the National Science Council (Republic of China).

\section{Conflict of Interest Statement}

We declare no conflict of interest involved in this study. 


\section{References}

1. Dembinska-Kiec, A.; Polus, A.; Kiec-Wilk, B.; Grzybowska, J.; Mikolajczyk. M.; Hartwich, J.; Razny, U.; Szumilas, K.; Banas, A.; Bodzioch, M.; et al. Proangiogenic activity of beta-carotene is coupled with the activation of endothelial cell chemotaxis. Biochim. Biophys. Acta 2005, 1740, 222-239.

2. Razny, U.; Polus, A.; Kiec-Wilk, B.; Wator, L.; Hartwich, J.; Stachura, J.; Tomaszewska, R.; Dyduch, G.; Laidler, P.; Schmitz, G.; Goralczyk, R.; et al. Angiogenesis in Balb/c mice under beta-carotene supplementation in diet. Genes Nutr. 2010, 5, 9-16.

3. Guruvayoorappan, C.; Kuttan, G. Beta-carotene inhibits tumor-specific angiogenesis by altering the cytokine profile and inhibits the nuclear translocation of transcription factors in $\mathrm{B} 16 \mathrm{~F}-10$ melanoma cells. Integr. Cancer Ther. 2007, 6, 258-270.

4. Hood, J.D.; Meininger, C.J.; Ziche, M.; Granger, H.J. VEGF upregulates ecNOS message, protein, and NO production in human endothelial cells. Am. J. Physiol. 1998, 274, H1054-H1058.

5. Huang, C.S.; Liao, J.W.; Hu, M.L. Lycopene inhibits experimental metastasis of human hepatoma SK-Hep-1 cells in athymic nude mice. J. Nutr. 2008, 138, 538-543.

6. Yang, C.M.; Yen, Y.T.; Huang, C.S.; Hu, M.L. Growth inhibitory efficacy of lycopene and beta-carotene against androgen-independent prostate tumor cells xenografted in nude mice. Mol. Nutr. Food Res. 2011, 55, 606-612.

7. Ribaya-Mercado, J.D.; Ordovas, J.M.; Russell, R.M. Effect of beta-carotene supplementation on the concentrations and distribution of carotenoids, vitamin E, vitamin A, and cholesterol in plasma lipoprotein and non-lipoprotein fractions in healthy older women. J. Am. Coll. Nutr. 1995, 14, 614-620.

8. Williams, A.W.; Boileau, T.W.; Clinton, S.K.; Erdman, J.W., Jr. beta-Carotene stability and uptake by prostate cancer cells are dependent on delivery vehicle. Nutr. Cancer 2000, 36, 185-190.

9. Palozza, P. Prooxidant actions of carotenoids in biologic systems. Nutr. Rev. 1998, 56, 257-265.

10. Young, A.J.; Lowe, G.M. Antioxidant and prooxidant properties of carotenoids. Arch. Biochem. Biophys. 2001, 385, 20-27.

11. Lin, C.Y.; Huang, C.S.; Hu, M.L. The use of fetal bovine serum as delivery vehicle to improve the uptake and stability of lycopene in cell culture studies. Br. J. Nutr. 2007, 98, 226-232.

Sample Availability: Samples of the compounds are available from the authors.

(C) 2012 by the authors; licensee MDPI, Basel, Switzerland. This article is an open access article distributed under the terms and conditions of the Creative Commons Attribution license (http://creativecommons.org/licenses/by/3.0/). 